\title{
A FEW OBSERVATIONS REGARDING WOO- DROW WILSON'S PRINCIPLE OF NATIONAL SELF-DETERMINATION AND ITS APPLICATION
}

\author{
Vladas Sirutavičius
}

ABSTRACT. This article briefly discusses traditional interpretations of the principle of national self-determination declared by President Woodrow Wilson. It is believed that the principle of national self-determination cannot be interpreted in isolation from specific historical conditions under which it was declared and implemented. Until the First World War the self-determination of nations was perceived more like the right to choose their (democratic) form of government ('internal self-determination'). During the war years the 'external' aspect of self-determination gained dominance, i.e. the right of a nation to be free from any 'alien' rule. Thus, technically the principle of self-determination of nations was supposed to mean both consolidation of national consciousness and democratization of society. However, implementation of the principle demonstrated that national self-determination might become a threat to democracy.

The political heritage of President Woodrow Wilson both in terms of theoretical and practical politics is often discussed by various researchers. Specialists of international relations are still attempting to identify the impact of Wilson's ideas on the foreign policy of the United States and international politics as well as the dynamics of international relations in general. Furthermore, we might claim that opinions and evaluations concerning the heritage in question are not uniform. ${ }^{1}$ Yet most of researchers agree that Wilson's ideas have still retained their relevance and influence in the foreign policy of the United States. ${ }^{2}$

${ }^{1}$ To some Wilson was the pioneer of the 'democratic intervention' doctrine and probably the most prominent advocate of the United States as a 'liberal empire'. Others believed that Wilson 'provided only an idealistic reasoning' for the actual imperialistic policy of the US. Cf. N. Ferguson, Colossus. The Rise and Fall of the American Empire (London, 2005), pp. 58-59; C. Johnson, The Sorrows of Empire. Militarism, Secrecy, and the End of the Republic (London, New York, 2006), p. 48.

${ }^{2}$ See L. C. Gardner, A Covenant with Power: America and World Order from Wilson to Reagan (New York, 1984); L.E. Ambrosius, 'Woodrow Wilson and George Bush: Historical Comparisons of Ends and Means in Their Foreign Policies', Diplomatic History, 30 (2006), pp. 509-543; S.G. Walker, M. Schafer, 'Theodore Roosevelt and Woodrow Wilson as Cultural Icons of US Foreign Policy', Political Sociology, 28 (2007), pp. 747-772. 
In general it may be said that two kinds of opinions prevail among historians concerning Wilson's political heritage. The first group of authors, usually referred to as liberal internationalists, regard Wilson as the prophet and creator of the modern period and a new global order. During his term (1913-1921) the United States abandoned their isolationist policy and became a power capable of changing the nature of international relations. Such scholars in fact support Wilson's belief that competition between states with autocracy, a closed economy and realpolitik, i.e. power competition among states, are the factors which render wars inevitable. In other words, global peace should be ensured by the spread of democracy (including the implementation of the principle of national self-determination), open economies and an international system of worldwide security. ${ }^{3}$ According to Henry Kissinger, the world as imagined by Wilson should be based on principles and not power; on law and not interests, and that was the total contrast to historical experience and methods of the great powers. ${ }^{4}$ Naturally, Wilson's contemporaries, political leaders of the 'old Europe' did not or would not understand the vision of a more democratic and secure world suggested by the US president.

The second group of authors are called realists. They prefer a different view of Wilson's ideas. Such scholars continue George Kennan's criticism of US foreign policy as 'moralistic and legalistic' which portrayed Americans as being 'more wise and noble than we really were'. 5 The so-called realists thought that Wilson's 'mutiny' against realpolitik, against power politics, was misguided. In their opinion, wars break out precisely because such power is ignored. Attempts by Wilson and his followers to transform the world and international politics were essentially unsuccessful due to one simple reason: the international system in its origin is anarchic. States in such a system compete for limited resources and, accordingly, have a limited desire for cooperation. Even in cases of cooperation among states, ambitions for power, and mistrust render universal security systems insufficiently effective and unable to deter aggressors. Thus, in the opinion of realists, Wilson's attempts to establish democracy

${ }^{3}$ A. Lynch, 'Woodrow Wilson and the Principle of 'National Self-Determination': A Reconsideration', Review of International Studies, 28 (2002), p. 419.

${ }^{4}$ H. Kissinger, Diplomatija (Vilnius, 2003), p. 213.

${ }^{5}$ G. Kennan, American Diplomacy (Chicago, 1984), p. 169; also see J. Knight, 'George Frost Kennan and the Study of American Foreign Policy: Some Critical Comments', The Western Political Quarterly, 20 (1967), pp. 3-4. 
(along with national self-determination) virtually could not ensure stability of international relations and particularly peace. ${ }^{6}$

We would probably be right to claim that the majority of arguments and disagreements among historians arise concerning the principle of self-determination of nations declared by Wilson. ${ }^{7}$ The declaration of that principle is usually associated with Wilson's speech delivered at the joint session of the US Congress on 8 January 1918. The socalled Fourteen-Points Speech defined the goals of the USA in the First World War. (Actually the term 'self-determination of nations' was not used in the speech.) Wilson described eight points out of fourteen as 'mandatory' to implement (open diplomacy, freedom of navigation upon the seas, universal reduction of armaments, elimination of trade barriers, impartial adjustment of colonial claims, the restoration of Belgium, the retreat of Germany from occupied territories in Russia, and the establishment of the League of Nations). The remaining six points were described as necessary but not 'mandatory' (returning Alsace-Lorraine to France, granting of autonomy to nations in Austro-Hungary and Turkey, readjustment of the frontiers of Italy, the retreat of Germany from the Balkans, internationalization of the Dardanelles and the creation of an independent Polish state with the territories inhabited by indisputably Polish populations, which should be assured an access to the Baltic Sea. ${ }^{8}$ We might say that three major views can be distinguished in the historical scholarship interpreting the principle of national selfdetermination and its relation with political practice. ${ }^{9}$

${ }^{6}$ F.J. Gavin, 'The Legacy of Woodrow Wilson: American War Aims in World War I', ORBIS, Fall, 1997, http://findarticles.com/p/articles/mi_m0365/is_n4_v41; last accessed on 14 April 2007.

${ }^{7}$ A more detailed survey of the literature might be found in: M. Pomerance, 'The United States and Self-Determination: Perspectives on the Wilsonian Conception', The American Journal of International Law, 70 (1976), pp. 1-27; D. Heater, National Self-Determination: Woodrow Wilson and His Legacy (New York, 1994), p. 225; Lynch, 'Woodrow Wilson and the Principle', pp. 419-436; L.E. Ambrosius, 'Dilemmas of National Self-Determination: Woodrow Wilson's Legacy', Wilsonianism: Woodrow Wilson and His Legacy in American Foreign Affairs, ed. L.E. Ambrosius (New York, 2002), pp. 125-143.

${ }^{8}$ D.M. Smith, 'The Fourteen Points', Encyclopedia of American Foreign Policy, ed. A. de Conde, vol. 2 (New York, 1978), p. 380; Kissinger, Diplomatija, pp. 212-213. Kissinger notes that some of the 'non-mandatory' points hardly corresponded with the principle of national self-determination and in his opinion the "moral symmetry of Wilson's plan was not ideal'. Still according to Kissinger 'Such revolutionary goals have never been presented with so few guidelines for their achievement'.

${ }^{9}$ For greater detail, see Pomerance, 'The United States and Self-Determination', pp. 3-26. 
The so-called idealists acknowledge the importance of the principle of national self-determination to practical politics and the development of international relations but also criticize Wilson for his lack of concern for its implementation. When the principle was attempted in practice 'double standards' were not avoided. ${ }^{10}$ Realists, on the contrary, believed that the principle of self-determination virtually could not be applied since it was a merely 'impractical moralizing slogan'. In the opinion of Robert Lansing, one of the first 'realist' critics of Wilson (during Wilson's presidency Lansing was the Secretary of State, 1915-1920) the principle of self-determination of nations only causes misleading and unsubstantiated illusions which might prompt political instability and competition among certain self-determination cases and eventually threaten global peace. ${ }^{11}$ Finally, according to the so-called 'radical' critics of Wilson the principle in question was merely a cover for the US

${ }^{10}$ Usually such critics as a good example of inconsistent politics associated with the principle of national self-determination indicated the Treaty of the USA and Japan signed already in October 1917 where Washington recognized 'special' interests of Tokyo in China (In fact the Treaty had a secret appendix stipulating that the parties would not seek 'special privileges' which would violate interests of citizens of China or other friendly countries). Another example is the US intervention in Eastern Siberia, already in summer 1918. According to some historians although the intervention was based on the geopolitical logic to prevent Japan from establishing its power in Siberia, but formally it contradicted the agenda of the Fourteen Points the sixth of which declared the evacuation of all Russian territory'. A. Iriye, The Cambridge History of American Foreign Relations, vol. 3, (Cambridge, 1995), pp. 48, 55-57.

${ }^{11}$ Naturally a number of political leaders of 'oppressed nations' in Central and Eastern Europe greeted Wilson's principle of national self-determination with enthusiasm seeing in it both a tool in the fight against the imperial policies and national oppression as well as an instrument for achieving national statehood. However, there were skeptics as well. Firstly, they doubted feasibility of the principle or rather understood that the principle in question could not be consistently applied in that region of Europe. Petras Klimas, the 'architect' of the national state of Lithuania, is a good example of such skepticism. He noted that in Lithuania 'the principle of national self-determination is not possible since it requires consciousness of the people and its consequences could be a good opportunity for demagogy'. (Elsewhere Klimas stated that 'it would be demagogic to ask a baby to say what he is. $\langle\ldots\rangle$ when people without culture are given the right of selfdetermination, it would serve as a chance for all sorts of agitators to fool them.') See: Lietuvos Valstybès Tarybos protokolai, 1917-1918 (Vilnius, 1991), pp. 73, 108. Therefore, for instance, territorial issues should be solved applying an objective ethnographic principle. More on application of Klimas' ethnographic principle in identifying the Lithuanian territories see: $\breve{C}$. Laurinavičius, Politika ir diplomatija (Kaunas, 1997), pp. 269-277. 
ambitions to expand their economic and then political influence in the world. Admittedly, during the First World War the principle of national self-determination made the process of collapsing empires manageable, and mitigated the threat of social radicalism and social revolutions. Thus, the principle of self-determination of nations so solemnly declared by Wilson was merely a political 'card' played in order to minimize the expansion of Bolshevism.

The present text is not intended as an argument as to which of the above mentioned interpretations of Wilson's principle of national self-determination is more substantiated. Ultimately, such a task would require a qualified historian international lawyer. The aim of this article is quite modest, i.e. identify a few, in our opinion more significant dilemmas encountered by the principle in question when from the sphere of ideas it entered a plane of practical politics.

\section{The First Dilemma: What did Wilson Say? Some American} and British historians maintain that until the outbreak of the First World War Wilson's thinking did not contain any direct or indirect references to the principle of self-determination of nations. ${ }^{12}$ (Particularly in the sense in which it is used nowadays, according to which the principle of national self-determination is often associated with a nation's right to create its national state.) In general, Wilson's political rhetoric dominated by such concepts as 'self-government' and 'government by consent'. There was one quite important reason for that, for Wilson understood a nation more politically than culturally. Thus, the subject of self-determination, i.e. a community or a nation, was not perceived in terms of cultural and ethnic differences, but in terms of a particular political organisation. Such concept of self-determination of nations was associated with the tradition of civic and liberal-national nationalism prevailing in America. Being a member of a community and a nation was based on an independent individual's decision (unlike in the dominating tradition of the Central and Eastern Europe where belonging to a nation was based on objective and usually cultural criteria.) Therefore, it follows that at least until the United States joined the war, the Wilsonian con-

${ }^{12}$ Pomerance, 'The United States and Self-Determination', pp. 1-2. In general US historians maintain that even at the onset of the war Wilson did not show any more attention to foreign policy and European matters, even more so to the 'national issue'. K.C. Clements, 'Woodrow Wilson and World War I', Presidential Studies Quarterly, 34 (2004), p. 64. 
cept of self-determination (in the sense of 'self-government' and 'government by consent') primarily meant a birthright to choose government and that choice was essentially opposite to autocracy and identical to a democratic political regime.

The question is what the relation of Wilson's principle of national self-determination was with multi-ethnic political systems, specifically with multi-ethnic imperial political structures dominating in Central and Eastern Europe (the Habsburg and the Romanov Empire). In other words, did Wilson by voicing a slogan for national self-determination want to prompt disintegration of such imperial structures? A straight answer to that is hardly possible. We might note at least a few aspects: (i) Wilson regarded autocratic political systems negatively, mostly because they limited the birthright freedom of individuals and their communities; (ii) Wilson was not essentially against a poly-ethnic political system. In his opinion poly-ethnicity did not prevent the United States to be a role model of 'autonomy' and accordingly of democracy to other communities. In fact, the modern US historians conclude that due to the said circumstances it would be incorrect to consider Wilson a 'destroyer of empires'; ${ }^{13}$ (iii) still, considering the general democratic content of the principle of self-determination, we might claim that it inevitably, irrespectively of the author's intentions had anti-imperial vectors; and iv) under circumstances of the war the principle of national self-determination in political practice was frequently subordinated to strategic interests of the US. Such assumption is supported by the practical policy of Washington regarding Austro-Hungary and Russia.

Historians note that already in December 1917 when the Fourteen Points agenda was drafted basically the multinational political structure of Austro-Hungary was understood as the 'self' element in 'self-determination', though it yet had to be freed from the influence of Germany. Wilson supported 'federalization of autonomous states in a strong democratic Austro-Hungary'. ${ }^{14}$ In general the political goals of the United States were not so much idealistic-moralistic (to satisfy aspirations of specific nations of empires) but rather strategic-military: to induce hostility among the Central Powers, to provide opportunities for separate peace with Austro-Hungary and to increase forces of allies. In other words, they sought to accelerate capitulation of Germany. According to researchers when it was

${ }^{13}$ Lynch, 'Woodrow Wilson and the Principle', pp. 429-431.

${ }^{14}$ For greater detail see: B.M. Uterberger, The United States, Revolutionary Russia, and the Rise of Czechoslovakia (Chapel Hill, 1989). 
certain that the US would not manage to 'separate' Austro-Hungary from Germany and outward processes were gaining dynamics in the dualistic empire, only then Washington chose the line of support to nations (on 29 May 1918 the US secretary of state declared that the US government 'had a fellow-feeling to national aspirations of Czechoslovaks and Yugoslavs').

What was the position regarding Russia? Washington quite enthusiastically welcomed the February Revolution and was one of the first to recognize the Provisional Government, by that both supporting democratic Russia and attempting to maintain the Eastern Front. When the Bolsheviks came to power, policy towards Russia became more cautious with the prevailing policy of waiting (American historians refer to it as 'passive'). ${ }^{15}$ Apparently Wilson considered a possibility to recognize the Bolshevik government de facto, but the State Department and particularly Secretary Lansing opposed the idea. ${ }^{16}$ (Naturally, it did not mean that Wilson had any liking for Bolshevik ideas of social radicalism, on the contrary, he did not. ${ }^{17}$ ) According to researchers, such policy continued almost until the spring of 1918 or rather until the Treaty of Brest-Litvsk. After it was signed the attitude towards the Bolsheviks was becoming even more negative. We might guess that the 'waiting' line of Wilson's policy regarding Russia was determined by two circumstances: firstly, a wish to maintain the Eastern Front against Germany. Secondly, we should not discount a possibility that such policy had certain geopolitical logic since Wilson believed that Russia (even with the Bolsheviks) was a substantial factor of security in the Eastern Europe. Such an assumption is confirmed by his idea of restoring Russia from the 'bottom upwards'. In January 1919 Wilson suggested calling a peace conference of all political units actually existing in the territory of the Russian Empire (including the Baltic States) and the Bolshevik government (except for Poland and Finland). ${ }^{18}$

${ }^{15}$ E.P. Trani, 'Woodrow Wilson and the Decision to Intervene in Russia: A Reconsideration', The Journal of Modern History, 48 (1976), pp. 447-448.

${ }^{16}$ Ibid., pp. 451-452.

${ }^{17}$ R. Hofstader, The American Political Tradition and the Men Who Made it (New York, 1989), pp. 358-359.

${ }^{18}$ More about the model of 'restoring' Russia from 'below' offered by Wilson in early 1919 see: Č. Laurinavičius, E. Motieka, N. Statkus, Baltijos valstybiu geopolitikos bruožai. XX amžius (Vilnius, 2005), p. 130. It also dwells on the circumstances and wording of the recognition of the Baltic States by the USA. The wording did not abandon the principle of integrity of Russia and recognizes not the Baltic States but their governments, ibidem, p. 136. 
Generally we may claim that the principle of national selfdetermination declared by Wilson by no means implied ethnic and political homogeneity, i.e. concurrence of cultural and political boundaries of a community. ${ }^{19}$ To put it differently, it is hardly possible to support a statement that Wilson was the herald of the "national principle' or an adept of a national state. We tend to believe that he was more concerned with more burning issues: firstly, to annihilate Germany, since its domination in Europe was considered a threat to US interests, and secondly, to find ways to minimize a risk of erupting nationalism.

Admittedly we cannot ignore the fact that the Wilsonian concept of the principle of national self-determination underwent certain evolution. Usually the relevant historiography widely cites Wilson's statements made already during the First World War, for instance, that 'every people has a right to choose the sovereignty under which they shall live' or that 'there is no law allowing passing people from one sovereignty to another as a property'. In historical publications such statements are mostly interpreted as disputable territorial issues of borders which should be solved considering the will declared by residents of those territories, in other words, based on the principle of self-determination of nations. ${ }^{20}$ According to historians, only in the war years did the tendency of Wilson's attitude to identify principles of 'nationality' and self-determination emerge. Accordingly, Wilson tended to believe that cultural and political (civic) communities were closely related. ${ }^{21}$ The concept of a nation also became more cultural-ethnographic and objective. However, the principle of self-determination of nations implied a choice of the democratic form of governing.

Summarizing, a few observations might be made:

Firstly, we may claim that the national self-determination for Wilson primarily meant 'the right of a community to self-government', i.e. selection of a political regime. That notion by no means implied that according to Wilson every ethnos had to have its own state.

Secondly, in Wilson's opinion the principle of national self-determination was of a universal nature, though with certain reservations 'when properly directed, there is no people in the world not fitted

${ }^{19}$ E. Manela, 'Woodrow Wilson and Colonel House', Diplomatic History, 31 (2007), p. 343.

${ }^{20}$ B.M. Unterberger, 'National Self-Determination', Encyclopedia of American Foreign Policy, ed. A. de Conde, vol. 2, (1978), p. 638.

${ }^{21}$ Lynch, 'Woodrow Wilson and the Principle', p. 424. 
for self-government'. However, the political practice of that period indicated that a consistent implementation of that principle was hardly feasible. In every specific case implementation of the principle of national self-determination depended on a number of factors (often their conjunctures) and more importantly the practical realization of the principle inevitably led to considering other principles of international politics (territorial integrity, non-intervention). Thus, in practice the principle of self-determination of nations declared by Wilson was applied only to the countries defeated in the First World War. It is equally important that the principle of self-determination was not applied to colonial nations. As a result of the Versailles conference Western countries received mandates to control the former colonies of Germany and Turkey, thereby as if readying them for the eventual 'self-determination'. Actually in practice this system became a cover for essentially colonial governing. ${ }^{22}$

Thirdly, until the First World War Wilson understood the principle of national self-determination as more 'internal', i.e. as the right to choose the form of governing. It differed from 'external self-determination of nations' or the right of a nation to be free from any 'alien' governing. Such concept became more prevalent in the war years. ${ }^{23}$

Fourthly, upon declaring the self-determination principle Wilson did not explain what the subject of self-determination was or what could and should be considered a nation and that fact allowed a rather loose interpretation of the principle.

The Second Dilemma of Democracy We would probably be right in saying that the shaping process of modern nations (along with the emergence of the principle of 'self-determination of nations') in the most general sense was associated with democratization of societies. However, it should be noted that in some cases consolidation processes of modern nations and national consciousness were more rapid, whereas in others they began later. Formally, the principle of self-determination of nations could mean both the pinnacle of consolidation of national consciousness and democratization. However, it did not happen. Implementation of the principle in practice demonstrated that self-determination of nations might become a threat to democracy.

${ }^{22}$ A few authors maintain that the principle of national self-determination declared by Wilson had an expressly manifested racial nature and was intended only for the white race. See Johnson, The Sorrows of Empire, p. 50.

${ }^{23}$ Pomerance, 'The United States and Self-Determination', p. 17. 
One aspect of such threat was distinguished by Dahrendorf maintaining that 'the concept of autonomous self-determination of nations formed at the time of collapsing empires after the First World War confirmed a rush to homogeneity which seemed to be characteristic of all societies. It also diminished the civic force diverting attention from its rights only for the sake of membership. ${ }^{24}$ Consequently, new states emerging on the basis of the principle of national self-determination (primarily in Central and Eastern Europe) were quite efficient in solving the problem of consolidating the national consciousness of their communities but not the establishment and strengthening of their democracies. There were a few reasons for such situation. On the one hand, ethno-linguistic, cultural nationalism acted as a sufficiently effective force consolidating a society, but it should be noted that such nationalism was not favourable to formation of a political culture of compromise. On the other hand, the formation history of 'new European' states evidences that different 'national decisions' not only strongly conflicted among themselves but were aggressive towards fellow citizens, i.e. national minorities. At least their aggression was not milder than that of a bureaucratic multinational empire.

The Dilemma of the Historical Context As we have mentioned above, the principle of national self-determination declared by Wilson may not be interpreted in isolation from specific historical conditions under which it was declared and implemented. Historians basically agree that one of the key factors influencing Wilson and his principle of self-determination of nations was the rise of the Bolsheviks to power and their overall reorganization of the society based on slogans of social radicalism. ${ }^{25}$ The principle of national self-determination in Bolshevik ideology was subordinated to the idea of the class struggle. Thus, national self-determination in Bolshevik conception and political practice was supported to the extent it promotes the class struggle. Consequently, the national self-determination was merely a means to achieve the main goal, i.e. the social revolution. Therefore, it was no coincidence that Bolshevik leaders campaigned for the principle to be implemented as consistently and universally as possible. ${ }^{26}$

${ }^{24}$ R. Dahrendorf, Modernus socialinis konfliktas (Vilnius, 1996), p. 61.

${ }^{25}$ Unterberger, 'National Self-Determination', pp. 636-637.

${ }^{26}$ A. Cassese, Self-Determination of Peoples. A Legal Reappraisal (Cambridge, 1996), p. 18. 
The last circumstance (overlapping of social radicalism with the national issue) was perhaps the most fundamental in implementing the 'national self-determination'. Academic literature contains a few claims that the Wilsonian principle of national self-determination was a certain 'card' with which to 'trump' the Bolshevik interpretation of the principle of national self-determination. Their authors believe that the Western principle of self-determination of nations was intended to decrease a threat of social radicalism brought by Bolshevik ideology and we might agree with such interpretation. Still we would dare to claim that the relation between the 'Wilsonian' and 'Bolshevik' principles was more complicated. Both Wilson and the Bolsheviks naturally were rivals, even hostile to each other, yet in some sense they were partners since both of them wanted to 'curb' the issue of nations. Thus, the Bolsheviks used it for the idea of a social revolution, whereas Wilson employed it for the idea of global peace.

\section{Author Details}

Dr Vladas Sirutavičius is a senior research officer at the Twentieth Century History Department of the Lithuanian Institute of History. His major academic interests are ethnic conflicts, relationships between Lithuanians and Poles as well as between Lithuanians and Jews. His last study (together with Č. Laurinavičius) was devoted to the recent history of Lithuania from Sajūdis to March 11 (Lietuvos istorija. Sajūdis nиo 'persitvarkymo' iki Kovo 11-osios).

Address: Lietuvos istorijos institutas, Kražių 5, LT-01108 Vilnius

Email: sirutavicius@istorija.1t

\section{KELIOS PASTABOS DE்L WOODROW WILSONO TAUTU APSISPRENDIMO PRINCIPO IR JO TAIKYMO}

Santrauka

\section{VLADAS SIRUTAVIČIUS}

Straipsnyje trumpai aptariamos dvidešimt aštuntojo JAV prezidento W. Wilsono deklaruoto tautų apsisprendimo principo interpretavimo tradicijos. Laikomasi nuostatos, kad tautu apsisprendimo principo negalima interpretuoti atsietai nuo konkrečių istorinių sąlygų, kuriomis jis buvo paskelbtas ir igyvendinamas. Iki Pirmojo pasaulinio karo tautų apsisprendimas buvo labiau suvokiamas kaip teisé pasirinkti savo - demokratinę - valdymo formą („vidinis apsisprendimas"). Karo metais èmė dominuoti ,,išorinis“ apsisprendimo aspektas, t. y. tautos teisè būti laisvai nuo bet kokio „svetimo” valdymo. Tiesa, paskelbęs apsisprendimo principa, Wilsonas 
nepaaiškino, kas yra apsisprendimo subjektas, kitaip tariant, ką galima ar reikètu laikyti tauta, o ši aplinkybe leido pakankamai laisvai interpretuoti pati principa.

Wilsono supratimu, tautų apsisprendimo principas buvo visuotinio pobūdžio. Tačiau jau to meto politinè praktika parodè, kad nuoseklus apsisprendimo principo igyvendinimas sunkiai įmanomas. Kiekvienu konkrečiu atveju tautų apsisprendimo principo igyvendinimas priklausė nuo daugelio veiksnių (dažnai konjunktūrinių) ir - tai, ko gero, svarbiau - šio principo politinis igyvendinimas neišvengiamai verte atsižvelgti i kitus tarptautinès politikos principus (teritorinio integralumo, nesikišimo). Taigi iš tikrujų Wilsono paskelbtas tautų apsisprendimo principas buvo pritaikytas tik Pirmajame pasauliniame kare pralaimejusioms valstybèms.

Formaliai žvelgiant, tautų apsisprendimo principas turèjo būti ne tik nacionalinès savimonès konsolidacijos, bet ir demokratizacijos kulminacija. Principo igyvendinimas tikroveje rode, kad tautų apsisprendimas gali kelti grèsmę demokratijai. „Naujujų" Vidurio ir Rytų Europos valstybių formavimosi istorija liudija, kad skirtingi „tautiniai apsisprendimai“ ne tik gana stipriai konfliktavo tarpusavyje, bet ir buvo agresyvūs savo bendrapiliečių - tautinių mažumų - atžvilgiu. Galima teigti, kad vilsoniškasis tautų apsisprendimo principas turèjo sumažinti socialinio radikalizmo pavojų, kurị kèlè bolševikinè ideologija. Antra vertus, Wilsonas ir bolševikai buvo savotiški partneriai, nes siekè tautų klausimą ,pažaboti“: bolševikai - ji pajungdami socialinès revoliucijos, o Wilsonas - pasaulinès taikos idejai. 